\title{
Nureddin Ferruh'un Postmodernimsi Bir Çocuk Olarak Portresi
}

\section{The Portrait of Nureddin Ferruh as a Postmodernish Child}

\section{Firat Caner*}

\section{$\ddot{O}_{z}$}

Nureddin Ferruh, 1896'da -henüz 17 yaşındayken- pek çok ustanın var olduğu Osmanlı edebiyat ortamında kendi şiir anlayışını bir manifesto olarak yazma ve yayımlama cesareti gösterir. Bu manisfestoda savunduğu yeni bir şiir anlayışının fikrî temelleri dönemin bütün genç yazarları üzerinde etkili olan Recâizade Mahmud Ekrem'in Talim-i Edebiyat'ında, esin kaynağı ise Abdülhak Hâmid'in şiirlerinde ve tercüme şiirlerdedir ${ }^{1}$. Nitekim Nureddin Ferruh kendi şiir anlayışını açıklar ve savunurken Recaizâde Mahmud Ekrem ve Abdülhak Hâmid'in şiirlerinden alıntılar yapar ve bu vesileyle kendi bakış açısını ve varsayımlarını meşrulaştırmaya çalışır. Onun yaşına göre pek cüretkâr olduğu söylenebilecek bu hamlenin ardında, Batılı bir eğitim/ öğretim yordamıyla hiyerarşi algısı örselenmiş (yahut teşekkül etmemiş) yeni bir neslin mensubu yani postmodern bir çocuk olması vardır.

Anahtar sözcükler: Osmanll, şiir, postmodernizm, batılılaşma, manifesto

\section{Abstract}

In 1896, when he was only 17 years old, Nureddin Ferruh ventured to publish his particular understanding of poetry as a manifesto in the presence of numerous masters

* Dr. Öğr. Üyesi. Karadeniz Teknik Üniversitesi. Türk Dili ve Edebiyatı Bölümü. firatcaner@yahoo.com 
in Ottoman literary scene. The intellectual foundation of this manifesto in which Ferruh offered a new understanding of poetry was based on Recaizade Mahmut Ekrem's Talim-i Edebiyat (Discipline of Literature) which exercised significant influence on young authors; and Ferruh's source of inspiration was the poetry written or translated by Abdulhak Hamid. As a matter of fact, when clarifying and justifying his particular understanding of poetry, Ferruh cites poems of Recaizade Mahmut Ekrem and Abdulhak Hamid thereby he attempts to legitimise his perspective and assumptions. Beyond taking this step, affirmingly a bold one considering his age, there lies the reason that Ferruh belonged to a new generation, that is to say, he was a postmodern child whose sense of hierarchy had been disrupted (or had not been formed at all) through the Western education.

Keywords: Ottoman, poetry, postmodernism, westernization, manifest

Modern sanata ilişkin sayısız görüşten yola çıkarak bir şiirin "Modern" olarak nitelendirilmesinin üç temel koşulu olduğu söylenebilir: Birincisi, sanayileşme ve kapitalistleşme sonrası Batı'da ortaya çıkan uygarlığın insan üzerindeki olumsuz etkilerinin izlerini taşıması; ikincisi, anlamın geriye itilmesi; üçüncüsü de vezin, durak, kafiye gibi şiirin şekil özelliklerinin geleneksel şiirden farklılık göstermesidir. Birinci koşul olmazsa, Modern ve çağdaş arasındaki ayrım ortadan kalkar. Bu nedenle birinci koşul olmazsa olmaz koşuldur. İkinci koşul, ancak birinci koşulla birlikte söz konusu olduğunda önem taşır; çünkü tek başına yetersizdir: Tek başına, her türlü anlaşılması zor şiiri Modern şiir kategorisi içine sokabilir. Üçüncü koşul da tek başına yetersizdir; zira her tür deneysel çabanın modernmiş gibi düşünülmesine sebep olabilir.

$\mathrm{Bu}$ çetrefilli durum aslında oldukça çizgisel, dolayısıyla da tarihsel seyri takip edilebilir olan Batı şiiriyle ilgilidir. Osmanlı söz konusu olduğunda Modern şiirin hangi ölçütlerle tespit edileceği konusu daha da çetrefildir. Zira Osmanlı sanayileşme ve kapitalistleşme sürecinden geçmemiştir. Dolayısıyla da Modernite'nin ürettiği hayat tarzı ve birey Osmanlı'da hiçbir zaman ortaya çıkmamıştır. Modernite'ye ait bazı fikirler Osmanlı kültürel yaşamına farklı anlamlar kazanarak girmiştir. Örneğin "Liberté" ile "hürriyet" aynı şey değildir, çünkü bir Fransız aydınının "liberté"den anladığı ile Namık Kemal'in "hürriyet"ten anladığı aynı şey değildir. Kelimeyle birlikte fikir de tercüme edilmiş, kendisinden başka bir şeye dönüşmüştür.

Modern Türk şiiri yedi ayrı ipliğin birbirine karışmasıyla ortaya çıkmış bir sarmala benzetilebilir. İpliklerden ilki "Batılı yazarların eserlerini okuma" ipliği (Şinasi), ikincisi "tercüme" ipliği (Şinasi), üçüncüsü "kısmî Modern düşünce" ipliği (Namık Kemal), dördüncüsü "kısmî Modern şekil” ipliği (Abdülhak Hâmid), beşincisi "şekil değiştirmiş modernist-ilerlemeci ideoloji ya da milliyetçilik" ipliği (Mehmed Emin Yurdakul), altıncısı "nostalji ya da muhafazakârlık" ipliği (Yahya Kemal, Ahmet Haşim, Mehmet Âkif Ersoy), yedincisi de "Modern kurumlar" ipliğidir (Nazım Hikmet’te sanayi, Orhan Veli'de şehir, İkinci Yeni'de Kapitalizm).

Türk şiiri modernleşirken birinci aşamada içerik değişmiş, klasik formların içinde alışılmadık temalar işlenmeye başlamıştır. İlk örnekler Şinasi’nin Müntahabât-ı Eş'ar'ında görülür (Uçman, 2014, s. 479). Tipik bir örnek Namık Kemal'in "Hürriyet 
Kasidesi"dir. Ancak kasideyi yazan kişinin aynı zamanda köleliğin normal kabul edildiği bir söylem üzerine inşa edilmiş olan İntibah adlı roman denemesinin yazarı olduğu unutulmamalıdır. Dolayısıyla, sultanı seçimle belirlemek ne kadar saltanatın ilgası ise, kaside formu içinde hürriyeti övmek de Osmanlı şiirinin kültürel bünyesini o kadar değiştirmektir. Namık Kemal'in (ve diğer 19. yüzyıl şairlerinin) şiiri farklı bir temaya sahip de olsa hâlâ tamamen Osmanlıdır ve hâlâ büyük ölçüde Divan şiiridir. Zira bu şairlerin eserlerinde modernleşmenin, yani kapitalistleşmenin ve sanayileşmenin sanc1ları görülmez.

İkinci aşama, formların değişmesidir. Bu aşamanın başrollerinde pratikte özellikle Sahra (1878) ile Abdülhak Hâmid (Törenek, 2010, s. 28) ve teoride de özellikle Takdîr-i Elhân (1885) ile Recâizâde Mahmud Ekrem vardır (Samsakç1, 2012, s. 20). Jean Cohen Structure du Langage Poétique adlı eserinde klasik şiir ile çağdaş (Modern) şiir arasındaki farkın duraklarla ilgili olduğunu söyler; çünkü çağdaş şiirde vezin durağının yerini anlamsal durak almıştır (Cohen, 1997, s. 62). Nermin Menemencioğlu da "Modern Turkish Poetry: 1850-1975" başlıklı makalesinde modern Türk şiirinin başlangıcının Abdülhâk Hâmid'in Sahra' yı yayımladığı yıl olan 1879 olduğunu öne sürer (Menemencioğlu, 1978, s. 49). Menemencioğlu'nun "modern şiir" için kullandığ 1 ölçüt de- Cohen'inki gibi- mısra yapısının bozulmasıdır: Ona göre Hâmid, mısraya dayalı yapıyı kıran ilk şairdir; bu nedenle de modern Türk şiirinin başlangıcı olarak kabul edilmelidir. Gérard Genette de Figures II'de, 20. yüzylla kadar, şiirle şiir olmayan arasındaki ayrımın vezne bağımlı olduğunu söyler (Genette, 1969, s.123). Türk şiirinde serbest vezinli ya da vezinsiz şiirler daha önce de yazılmış olmasına rağmen, dizeyi şiirin egemen öğesi olmaktan çıkartan Nâzım Hikmet'tir. Ahmet Haşim'in de serbest müstezat denemeleri vardır; Ercüment Behzat Lav ve Nâzım Hikmet veznin özgürleştirilmesinde zamandizinsel olarak Hâşim'den sonra gelir. Ancak serbest vezni Türk okuruna benimseten şair Nâzım Hikmet'tir. Vezinsiz şiiri benimseten ise Garip şairleri, yani Orhan Veli, Oktay Rifat ve Melih Cevdet Anday'dır.

Üçüncü aşama, sanayileşme ve Kapitalizmin etkilerinin hissedilmesi ve şiire taşınmasıdır. Bu aşamayı deneyimleyen ilk şair nesli Ercüment Behzat Lav-Nâzım Hikmet Ran neslidir. Ancak bu bağlamda "Modern" denebilecek asıl şiirler İkinci Yeni hareketi ile birlikte ortaya çıkar.

Nureddin Ferruh, Türk şiirinin modernleşmesinde bir öncü değil bir sonuç, bir merhale değil bir ândır. O, Abdülhak Hâmid ve Recaizâde Ekrem'in inşa ettikleri şiir ortamının içinde yetişen ve şiir zevki bu ortamın Osmanlı şiiri için deneysel olduğu söylenebilecek örnekleriyle şekillenen bir neslin, henüz şekillenmekte olan yeni şiir zevkinin manifestosunu yazan ilk örneğidir ${ }^{2}$. İçinde yetiştiği ortamda sanayileşme ve Kapitalistleşme söz konusu olmadığından Modern değildir; ama Moderniteyi deneyimleyen toplumların felsefe ve şiirinin tercümesi sayılabilecek bir kültür ortamında yetiştiği için Modernisttir: "Garb kültürü ile temasım Avrupa medeniyeti hakkında beynimde şedîd iştiyak meşalesi yakmış ve Avrupa'da tahsil arzusu bende sabit fikir halini almıştı [...] Ben ise [...] garp muhiti, garp havası, garp medeniyeti ve bilgileriyle yetişmek hevesinde idim" (Ferruh, 2017, s.28). Modernisttir, çünkü onun için Modernlik bir olasılık, bir olanak, bir seçenek değil; (kavuşmayı hevesle beklediği) 
kaçınılmaz sondur. Bugünden geçmişe yönelen bir bakışla değerlendirildiğinde Nureddin Ferruh'u önemli kılan da bu yönüdür. Yirminci yüzyılda aşama aşama normalleşecek, ancak o dönemde sıra dışı olduğu düşünülen görüşleri kişisel başarısızlığı göze alarak benimsemiştir.

\section{Postmodernimsi bir çocuk: Nureddin Ferruh}

19. yüzyılın son on y1lında yetişen ve 17 yaşındayken ${ }^{3}$ ön sözünde şiir sanatına dair kanaatlerini anlattığı bir şiir kitabı yayımlama cüreti gösteren Nureddin Ferruh ${ }^{4}$ (1877-1955)5, muhtemelen, Türk şiirinin "Postmodern" sözcüğü icat edilmezden evvel yaşayıp yazarlık yapmış ilk Postmodern(imsi) çocuğudur. Burada "Postmodern çocuk" ile kastedilen, Osmanlı münevverlerinin yüzyıl Avrupa'sının eğitime ilişkin uygulamalarından anladığı kadarıyla aktardığı, yarı münevverlerin de bu aktarılanlardan anlayabildiği kadarıyla uyguladığı, aile içindeki ve sosyal hayattaki geleneksel kültüre temas etmesiyle beklenmeyen sonuçlar ortaya çıkartan ve Batılı olduğu iddia edilen bir çocuk yetiştirme yordamının sebep olduğu bir yeni insan tipidir.

$\mathrm{Bu}$ insan tipinin ayırt edici özelliklerinin başında hayatın ve zihnin üzerine inşa edildiği kavramların ve dolayısıyla göstergelerin içinin boşaldığ 1 , bu sebeple de göstergelerin yerini aşırı göstergelerin aldığı bir dünyanın, yani Batılılaşmaya başlayan üçüncü dünyanın bir temsilcisi olması gelir? . Hilmi Yavuz'a göre bu olgu parçalara bütünü temsil etme yetkesi atfedilen bir modernleşme tarzında kendini ifşa eder ${ }^{8}$. Örneğin, Osmanlı romanında Batılılık (yahut Batılılaşmışlık) piyano çalmak, Fransızca konuşmak gibi simgeler üzerinden ima edilir. "Piyano çalmak", "Fransızca konuşmak" vb. birkaç gösterge bir araya gelerek Batılı olmakla ilgili bir içi boş göstergeler kümesi ${ }^{9}$ üretir. Artık göstergelerin içi boştur; çünkü mevcut dünya, Fransızca konuşan bir kişinin Fransız olduğundan emin olunması imkânsız bir dünyadır. Tam da bu yüzden, Batılılaşma denen şey-modernleşmeden farklı olarak- tabiatı itibariyle Postmoderndir.

Modernleşme, Batı'da cemaat toplumunun tarihsel gelişmelerin sonucu olarak geçirdiği evrimin adıdır. Burjuvazinin ortaya çıkışı, sanayi devrimi, kentleşme, uluslaşma, demokratikleşme vb. süreçler nihayetinde modern toplumun ortaya çımasını sağlar. Bu dönüşüm elbette yeni toplumsal ihtiyaçları, yeni toplumsal ihtiyaçlar yeni eğitim/öğretim yordamlarını ve nihayetinde bu yordamlar da yeni insan tiplerini de beraberinde getirir: Vatandaş, serbest müteşebbis, yönetici, çocuk vs. Bu yeni insan tipleri aşama aşama ve gelişen ihtiyaçlarla eşzamanlı olarak ortaya çıktı̆̆ için Batı'da geleneksel toplumu ayakta tutan hiyerarşi çözülmemiş, dönüşmüştür.

Osmanlıda ise Batılılaşma, Kanuni Sultan Süleyman'ın Fransa Kralı I. François'ya yazdığı meşhur mektubunda açıkça görülen Avrupa karşısındaki büyüklük ve güçlülük duygusunun yitirilmesiyle teşebbüs ${ }^{10}$ olarak başlar ${ }^{11}$ Güçlenmek, güçlünün güçlenirken yaptıklarını yapmayı gerektirir. Ancak 19. yüzyılda Osmanlıların Avrupa'nın güçlenirken yaptıklarını tespit etmesi, uygulaması neredeyse imkânsızdır. Bu yüzden olsa gerek, Avrupa'nın o çağını inşa eden geçmişini değil, o anki hâlini taklit etmeyi denerler ${ }^{12}$. Bunun için de kendi iktidar alanları, yani imparatorluk coğrafyasındaki imkânları seferber etmeye çalışırlar. Ancak ellerinde ne ulus-devlet ne kapitalizm ne de gerçek 
anlamda bir modernleşmenin üstyapısını kurgulayabilecek bir entelektüel sınıf vardır. Dolayısıyla Batılılaşma teşebbüsleri yol kat edemez.

Osmanlı Batılılaşmasının teşebbüsten ibaret olmayan ikinci aşaması, güçlü Avrupa'nın imparatorluğun içine nüfuz etmesi ve devletin iç işleri üzerinde belirleyici olması ile yakından ilgilidir. Bu aşamanın Tanzimat Fermanı, Islahat Fermanı gibi hamleleri büyük ölçüde Avrupa devletlerinin baskıları sonucu ve Osmanlının o zamana kadarki öncelikli tebaasının aleyhinedir. Elbette dayatılan her türlü değişim, dayatıldığı kişi ya da toplulukların arzu, ihtiyaç ve alışkanlıkları ile bir araya geldiğinde çok sayıda ve sonuçları öngörülemez bir tepkime silsilesi ortaya çıkarır. Anadolu İslam'1 nasıl temellük edilen İslam'ın, mevcut bulunan ve Anadolu'daki Helen paganizmi ile iç içe geçmiş Türk Şamanizm'inin ve daha pek çok şeyin etkileşmesinin kısmen rastlantısal bir sonucu ise, Osmanlı Batılılaşması da öyle Batı kültürü, Avrupa devletlerinin talepleri, hanedanın hayalleri, münevverlerin ve toplumun ileri gelenlerinin değişime gösterdikleri direnç ile tarihsel zorunluluklar ve mevcut koşullar arasındaki etkileşimin k1smen rastlantisal bir sonucudur.

Postmodern çocuk da benzer bir zincirleme tepkimenin sonucudur. Bugün "çocuk" dediğimiz belirli bir yaşın altındaki kişiler geleneksel toplumlarda yetkinlikleri ölçüsünde yetişkinlerle birlikte, onlarla aynı hayatı yaşar. $\mathrm{Bu}$ iç içe yaşantının çatışmasız bir şekilde sürdürülebilmesi, sınırları açıkça çizilmiş bir hiyerarşinin varlığına ve işlerliğine bağlıdır. Bu sayede geleneksel toplumlarda herkes yerini ve haddini, dolayısıyla da sorumluluk ve yetkilerini iyi bilir. Geleneksel toplum -yani cemaat toplumu- bilenin konuştuğu, bilmeyenin susup bileni dinlediği bir düzene sahiptir. Bu sebeple geleneksel bir toplumda 10 yaşındaki bir kişi bile usta olabilir (Karatani, 2011, s. 135-158).

Geleneksel toplumda bilgi sahibi kişi, hem o bilgiyi kullanarak belirli bir ihtiyaca cevap veren ve bu sayede geçinen, hem de sahip olduğu bilgiyi usta-çırak ilişkisi denebilecek bir hiyerarşi içinde bir sonraki nesle aktaran kişidir. Usta aynı zamanda kendisinin patronu ve çırağı beğenmediği takdirde yetiştirmekten vazgeçme hakkının da sahibi olduğu ve ustaya hürmet bilmeyen bir kişi hayatını kazanmasını sağlayacak bir eğitimden mahrum kalacağı için bu düzende ustanın sözü kanun sayılır. Tam da bu sebeple geleneksel toplumda bir kişi eğitim için ustaya verilirken "Eti senin, kemiği benim." denilir. Kemiklerini kırmadığı, yani kalıcı bir hasar bırakmadığı sürece usta çırağı dövmek hakkına da sahiptir. Çünkü öğrettiği şey çırak için hayatidir; onun gelecekte hayatını idame ettirmesini sağlayacaktır. Çıraklık evresinde bile bir işe yaradığı ve bir kazançta pay sahibi olduğu için az da olsa kazanç söz konusudur. Usta öğretmek için öğretmez, çırak öğrenmek için öğrenmez.

Batının ihtiyaçlarına uygun olarak üretilmiş yeni eğitim/öğretim yordamı, Osmanlıda toplumsal ihtiyaçlardan değil, siyasi ve ekonomik zorunluluklardan dolayı devreye girer. Bir ihtiyaca cevap vermediği için de ihtiyacı kendisi üretmek zorunda kalır ${ }^{13}$ Ortada otantik bir toplumsal ihtiyaç bulunmadiğından, bu yordam, sorumluluk/ yetki birlikteliğini üretemez. Zira yeni tip öğretici bir usta değil, bir öğretmendir ve öğrenci, hiç değilse öğrencinin ailesi onun müşterisi/patronudur. Geçimini bir usta gibi öğrettiği işin ürününü satarak değil, öğrettiği kişiyi ve ailesini memnun ederek sağlar. 
Dolayısıyla öğretici ile öğrenen kişi arasındaki hiyerarşi kırılmış olur. Öğretici öğrettiği şeyin ustası değildir; Tanzimat İstanbul'unda Fransızca öğreten mürebbiyeler dönemin Fransız dili uzmanları arasından çıkmamıştır. Bununla birlikte öğrenim görenler de talebe değil öğrencidir; zira öğreticilerin yanına gerçek ve yaşantılarına yönelik bir talep ile gelmezler. İkisi de bir ihtiyaç sonucu ortaya çıkan bir işlevi değil, bir rolü üstlenmiştir. Öğretmen öğretmek için öğretir, öğrenci de öğrenmek için öğrenir ${ }^{14}$ Böyle bir ilişki düzleminde hiyerarşinin örselenmemesi elbette mümkün değildir. Üstelik bu, bütün geleneksel toplumsal hiyerarşilerin ç̧̈zünüşünün örneklerinden sadece biridir.

Geleneğin içinden üretilmeyen, bunun yerine geleneğin üstüne giydirilmeye çalışılan bir modernlik projesinin bütün olası sonuçları, ilk andan itibaren Postmoderndir. Mevcut kültürel koşullar içinde Batılı bir eğitim/öğretim yordamıyla hiyerarşi algısı örselenmiş (yahut teşekkül etmemiş) bir grubun ortaya çıkışının zeminini hazırlar. Bu grubun mensupları literatürde "yanlış Batılılaşmış", "züppe", "Batı özentisi”, "Mösyö" vb. şekillerde anılır. Oysa bu tip, belirli bir zihniyetin tezahürlerinden sadece biridir. Cahil ama bilmiş, marjinal ama muhafazakarmış gibi görünen ya da yobaz ama ilerici geçinen, liyakat sahibi olmaksızın mevki, sorumluluk üstlenmeksizin yetki sahibi olmayı doğuştan bir hak olarak gören bir zihniyettir söz konusu olan. Geleneksel bakış açısıyla postmodern çocuğun -günümüzde de teşhis edilebileceği üzere- tipik tavrı da yukarıda söylenenlerden anlaşılabileceği üzere hadsizlik ve densizliktir. Geleneksel bakış ile kuşatılmış bu grup da siyasette özgürlükçü, sanatta deneycidir.

\section{Teoride Nureddin Ferruh}

Baş teşrifatçı Ferruh Bey'in dünyaya gelen oğlu Nureddin Ferruh henüz on yedi yaşındayken bir miktar edebiyat terbiyesine sahip olmuş, edebiyat tarihinden örnekler vermek suretiyle savunduğu bir manifesto kaleme almış ve bu yazıda beyan ettiği fikirleri gerçekleştirmek suretiyle küçük bir kitap hacminde bir uzun şiir yazarak 1895 yılında Şafak Sadaları ismiyle yayımlamıştır. Çağ, Batı'da genç şair Arthur Rimbaud'nun parladığı, şiirde deneyim ve ustalık fetişizminin yerle bir olup yenilik ve cesaretin kutlandığ 1 bir çağdır. Bununla birlikte Osmanlı henüz her türlü yeniliğin sadece yenilik olması sebebiyle kutsandığı Faustvâri kültür ikliminin tam anlamıyla etkisi altında değildir ve her ne kadar Tanzimat edebiyatıyla birlikte büyük yenilikler ortaya çıkmışsa da Türk şiirinin kültürel bünyesi ${ }^{15}$ henüz vezin ve kafiyeden tamamen bağımsız bir metnin şiir olarak kabul edilmesine hazır değildir. Nureddin Ferruh biçimsel özellikleri bakımından henüz Divan edebiyatının etkisinden tamamen kurtulamamış bir şiir ortamında şiirde vezin ve kafiyenin şart olmadığını savunmuştur. Oysa o sırada kültür ortamı kafiyenin göz için mi yoksa kulak için mi, vezninse aruz mu yoksa hece mi olmasının makbul olacağı tartışmalarının yaşandığı bir ortamdır.

Nureddin Ferruh şiirde biçime ilişkin sıra dışı önerilerde bulunmakla yetinmez; y1llar sonra, önce Yeni Lisan hareketi, daha sonra da Ziya Gökalp'le Türk kültür iklimi üzerinde belirleyici olacak, Türkçenin yabancı terkiplerden arındırılması, ancak Türkçenin ahengiyle uyum içindeki yabancı kelimelerin korunup uymayanların uygun hâle getirilmesi önerisini de getirir. Arapça ve Farsça kaynaklı zincirleme terkiplerin 
Türkçenin ahengini bozduğunu, üstelik anlam bakımından gülünç olduklarını ve bu gülünçlüğün terkiplerin yabancı bir dile çevrilmesi hâlinde apaçık görülebileceğini söyler (Ferruh, 1895, s. 70-71).

Sevim Şermet, Şafak Sadaları'nın "üç beş aydan beri şiire heves eden bir genç tarafından on yedi yaşında kaleme alınmış bir eser" olduğunu söylerken (1339) Nureddin Ferruh'un kitabının başındaki (1895, s. 15) beyanını esas alır. Bununla birlikte baş teşrifatçı Ferruh Bey'in oğlu olan Nureddin Ferruh, Rıza Tevfik'ten edebiyat ve estetik dersleri almıştır (Uçman, 2012, s. 212). Henüz on yedi yaşında şiirle ilgili edebiyat tarihine atıflarla fikirler yürütmesi ve birbirinden ayrı küçük manzumeler değil, birbirine bağlı dört kısımdan oluşan yekpare bir manzume kaleme almış olması bu beyanın ilm-i siyasetten olduğu kanaatini uyandırır. Bu sebeple Nureddin Ferruh kendisini şiire yeni heves etmiş bir genç olarak tanıtmakla kendini bir dâhi gibi göstermeye çalışmış olabilir. Bununla birlikte, -sıra dışı bir şairlik yeteneği olmamasına rağmen- çağdaşları arasında hem sıra dışı hem de öncü bir rol üstlenmeye yeltenmiş ve Türk şiirinin geleceğini önceden görebilmiştir. Fakat kültürel bünye henüz bazı yeniliklere hazır olmadığından olsa gerek, bu öngörüsü ona Türk edebiyatı tarihinde bir yer edinmesi bakımından bir avantaj sağlayamamıştır.

On yedi yaşındaki Nureddin Ferruh, pek çok ustanın var olduğu bir edebiyat ortamında kendi şiir anlayışını bir manifesto olarak yazma ve yayımlama cesareti gösterir. Bu manisfestoda savunduğu yeni bir şiir anlayışının fikrî temelleri dönemin bütün genç yazarları üzerinde etkili olan Recâizade Mahmud Ekrem'in Talim-i Edebiyat'ında, esin kaynağı ise Abdülhak Hâmid'in şiirlerinde ve tercüme şiirlerdedir ${ }^{16}$. Nitekim Nureddin Ferruh kendi şiir anlayışını açıklar ve savunurken Recaizâde Mahmud Ekrem ve Abdülhak Hâmid'in şiirlerinden alıntılar yapar ve bu vesileyle kendi bakış açısını ve varsayımlarını meşrulaştırmaya çalışır. Şiirde kafiye ve veznin önemli olmadığını, kendi kitabını da mevzun değil, manzum olarak yazdığını söyler (Ferruh, 1895, s. 25). Şafak Sadaları biçim özellikleri bakımından sahiden de dönem şiiriyle örtüşmez ve sonuç itibariyle devrin yazarları tarafından şekil özellikleri itibariyle ağır eleştirilere maruz kalır (Uçman, 2012, s. 212).

Bu ölçüde tepki alması, fikir olarak kaldıkları sürece daha önce başkalarınca da ifade edilmiş olmalarından ötürü pek de yadırgatıcı olmayan fikirlerini beyan etmesinden ziyade, on yedi yaşında bir genç olarak o fikirleri kuvveden fiile geçirmek suretiyle Şafak Sadaları'nı yazması ile ilgili olsa gerektir. Çünkü ondan önce mesela Recâizâde Mahmud Ekrem "Zemzeme III"te "her şiir mevzûn ve mukaffâ olmak lâzım gelmez" diyerek her şiirin vezinli ve kafiyeli olması gerekmediğini belirtmiştir. Veznin ve kafiyenin gözetilmediği şiirler de yazılmıştır. Mesela Ali Kemal 1884'te ${ }^{17}$ yayımladığ 1 "Öyle de Yazllabilir Böyle de" başlıklı görsel şiirini hem görsel hem de biçimsel özellikleri bakımından sıra dışı bir anlayışla kaleme almış, birden çok vezni aynı anda kullanarak bir serbest vezin örneği vermiş̧ir (Akın, 2001, s. 73-74). Görsel şiirin (concrete/pattern/ visual poetry) yaygın olmasa da Osmanlı şiir geleneği de dâhil olmak üzere hemen hemen bütün yazılı geleneklerde örneklerinin bulunduğu, dolayısıyla da çok sıra dışı yahut yeni bir şey olmadığı göz önünde bulundurulmalıdır ${ }^{18} \mathrm{Bu}$ şiirdeki asıl yenilik vezin 
ve kafiye kullanımındaki iç tutarsızlık ile ilgilidir.

Asıl büyük öncü ise devrin şair-i azâmı Abdülhak Hâmid'dir. Hâmid, Türkçe şiirde kelimeleri vezne uydurma teamülünü bozmuş, Yadigâr-l Harb adlı eserinde bilinen aruz tef'ileleri ile kullanılması mümkün olmayan sözcükleri şiirinde kullanabilmek için yeni tef'ileler icat etmiştir. Duhter-i Hindû' nun "Hâtime" adlı bölümünde kitapta yer alan "Tagannum Manzumesi”yle Batılı tarzda şiiri Türkçede tecrübe ettiğini söyler (Kebeli, 2007, s. 23). Ayrıca Hâmid, tiyatro eserlerini aruz ile kaleme almak suretiyle, Batılı bir tür olan tiyatroyu Osmanlılaştırmaya çalışırken, dönem okurlarının zihnindeki şiir algısını Batılılaştırmıştır. Nitekim Bruijin'in sözleriyle Hâmid, eserini Batı'nın manzum drama yapısı ile Osmanlı Türk şiir geleneğini birleştirerek kurgulamıştır (Brujin, 1997, s. 23).

Kısaca, Nureddin Ferruh'un şiir sanatı hakkındaki fikirleri Osmanlı edebiyatçıları arasında rast gelinmemiş, taze fikirler değildir. Bunlar genel itibariyle Avrupa şairlerince ortaya atılmış, şiire uygulanmış, daha sonra Osmanlı şairlerince öğrenilmiş ve çeşitli şairlerce ifade edilmiştir. Bununla birlikte varlığı bilinen ve tek tük de olsa bazı şiirlerde (hepsi aynı eserde olmamak üzere) uygulamaya koyulan bu fikirler henüz Osmanlı şiir ortamında kabul görmemiştir. Nureddin Ferruh edebiyat ortamında kabul görmemiş yenilikçi fikirlerin hepsine birden aynı anda, aynı yazıda sahip çıkmış ve hepsini birden aynı şiirde uygulamayı denemiştir: "O halde Nureddin Ferruh'un bu kitabında söylediği birçok şey esasında Tanzimat neslinden başlayıp kendisinin de dahil olduğu Ara Nesil sanatçıları arasında sürüp giden kalem kavgalarının ve eski-yeni münakaşalarının bir yekunundan başka bir şey değildir” (Kolcu, 2017, s. 42). Nâzım Hikmet ortaya çıkana kadar da hiç kimse Nureddin Ferruh kadar şiirin yaygın olarak kabul gören özelliklerini zorlamayacaktır.

\section{Pratikte Nureddin Ferruh}

Nureddin Ferruh, çok genç olmasına rağmen Malûmat dergisinde yayımlanan "San'at" (1896, s. 710-712, s. 869-871) başlıklı yazısında sadece edebiyata değil antropoloji, felsefe, psikoloji, resim, heykel, mimarlık, şiir, müzik gibi pek çok konuya dair - bu tür konularda bahis açabilecek seviyede- malumat sahibidir. Servet-i Fünûn'da yayımlanan "San'at" (1896, s. 262) başlıklı yazısındaki Natüralizme ilişkin tartı̧̧malarda da hem sanat felsefesi ile ilişkisinin derinliği hem de orijinal Fransızca metinlere aşinalığı görülebilir. Bu satırları yazan 10 senelik öğretim üyesi 40 yaşında bir felsefe meraklısı olmasına rağmen, Nureddin Ferruh'un atıfta bulunduğu isimlerin bazılarını tanımamaktadır. Anlaşılan o ki Rıza Tevfik'in rahle-i tedrisinden geçmiş olması, Nureddin Ferruh'a apaçık bir entelektüel avantaj sağlamıştır.

Nureddin Ferruh'un şiirle ilgili görüşleri Şafak Sadaları önsözünden seçilmiş kendi cümleleri ile kısaca şöyledir:

"Vezin ve kâfiyesi muntazam veyâhûd hissiyyâtı tamam fakat ciddiyyet, ulviyyet, tesîr, bedâyi-i hayâliyye gibi mehâsin-i tabîiyyeden mahrûm olan sözlere şiir nazarıyla bakılamaz./Yukarıda söylediğim dört şarttan ikisi, yahûd biri eserde mevcûd olup diğerleri veyâhûd yalnız biri mefkûd olsa, o nazımdır, ona şiir denemez.[...] Evvelce 
de söylediğim gibi vezin ve kâfiye şiir için kâfî̀ değildir. [...] Zîrâ şiiri evzân-1 malûme ile kâide tahtına almak gareziyle tesirinden mahrûm etmek câiz olamadığı gibi, bir şiir-i hakîkîyi de kâidesizdir diye atmak münâsib değildir. [...]Eşârın katiyyen mevzûn yazılmaması fikrinde değilim. Şu kadar ki mutlakâ mevzûn olanlara şiir denilebilip mevzûn olmayanların şiirden addolunamayacağı fikrini de tecvîz edemem. Fikrimce her iki tarz da kabûl olunmalıdır; zîrâ bazı şiir olur ki vezin ile yazılırsa güzel ve bazısı da bu tarzda yazılırsa latîf ve şîîn olur."

$\mathrm{Bu}$ görüşlerin geçerliliğini göstermek amaciyla Recaizâde Mahmud Ekrem, Riza Tevfik, Abdullah Cevdet gibi isimlerin, özellikle de Tanzimat şiirindeki pek çok yeniliğin öncüsü olan Abdülhak Hâmid'in eserlerinden örnekler verir. İçinde yer aldığı gelenekle kurduğu yegâne bağ da budur.

Nureddin Ferruh'un şiiri Osmanlı Türkçesi ile yazılmış ve Divan şiirinde kullanılan "gülşen" vb. geleneksel bazı imgelerle süslenmiş de olsa, Osmanlı olmaktan ziyade Fransız'dır. Şiirde geçen ilk mekân bir şatodur. İlk atıf dağ perilerinin ismi olan "Helikon" ile Helen mitlerinedir. Şiirdeki âşı söylemi geleneğe aykırıdır; zira şiirde konuşan kişi hitap ettiği sevgiliye, âşığa cefanın reva olmadığını söyleyerek sitem eder. Ayrıca perinin ellerini öpmesi de şiirdeki Fransız - muhtemelen romans- etkisinin bir göstergesidir.

Nureddin Ferruh, biçim özellikleri bakımından Abdülhak Hâmid'in, şiire ilişkin düşünceleri bakımından Recaizâde Mahmud Ekrem'in açtığı yolu kulladığı gibi, dinî söylem bakımından da Akif Paşa'nın "Adem Kasidesi" ile açttğı yolu kullanır ve sevgiliye olduğu gibi Allah'a da sitem eder; hatta ondan hesap sorar: "Rahm et eyvâh amân yâ Rab/Niçin ettin beni mağdûr/Şemsim kadrim önümde gârib,/“Ömrüm âmâde iken yoluna/Yâ bu şâyeste midir kuluna?” Edebiyat dünyasına adımını atarken, Tanzimat şiirinin başlıngıcından o güne değin tam olarak ya da kısmen uygulanmış bütün yenilikleri benimsemiş, bu yeniliklerin hepsini bir potada eritmeye çalışmıştır. Ancak büyük bir şiir yeteneğinin bulunmayışı sebebiyle olsa gerek bu öncü tavrı ne onu ne de eserini Türk edebiyatı tarihinin öne çıkan figürlerinden biri k1lamamıştır.

Sınırlı edebiyat bilgisi ve yazma tecrübesine sahip 17 yaşında bir çocuk olarak şiir kitabı yayımlamakla kalmamış, kitabında şiir sanatıyla ilgili görüşlerini bir usta edasıyla özetlemiştir. Bunlar Avrupa şiirinde kuvveden fiile geçmiş, ürünlerini vermiş, Osmanlı şiirinde de Recaizâde Mahmud Ekrem tarafindan teorik olarak ifade edilmiş, Abdülhak Hâmid tarafindan kısmen, Ali Kemal tarafindan resmen uygulanmış, ancak mevcut şiir kültürünü dönüştürmemiş, moda hâline gelmemiş, bir şiir hareketi oluşturmamış, dolayısıyla da genel olarak kabul görmemiş görüşlerdir. Nureddin Ferruh bu görüşlerin hepsini bir arada, aynı şiirde, mevcut şiir geleneğinin teamüllerini kendince darmadağın ederek uygulamaya çabalamış ve nihayetinde başarısız olmuştur. "Şafak Sadaları" niteliksiz bir şiir olması sebebiyle edebiyat tarihinde bir iz bırakamamış, müellifi de tarihe bir siyasetçi ${ }^{19}$ ve bir Hariciye mensubu olarak geçmiştir. Ama Nureddin Ferruh kültürel bakımdan melez bir yeni tip çocuk olduğu için şiirinin yetersizliği için bahanesi de hazırdır: Parçaları eksik yayımlamıştır; eser bu yüzden kusurlu gibi görünmektedir.

Nureddin Ferruh Modern değildir ama Modernisttir. Postmodern değil Postmodernimsidir zira Postmodernite henüz mevcut değildir. Yazdığı şiirin durumu da 
böyledir. Ne idüğü belirsiz bir niteliksiz edebiyat örneğidir ama şairin biçim tercihleri bakımından çağdaşlarının çok ötesindedir.

\section{Notlar}

1 Ali İhsan Kolcu bu hususta şöyle der: "Şafak Sadâları'nda yazarın [...] Abdülkhâk Hâmid ve Recaizâde Ekrem'den mülhem görüşlerini bir kurgu dahilinde kotardığını görürüz”. Serbest Şiirin İlk Kuramcısı, (Erzurum: Salkımsöğüt Yayınevi, 2017), s./ p. 37.

2 Abdulhalim Memduh, 1888 yılında, Bedriye adlı manzum tiyatro eserinin giriş kısmındaki "Birkaç Söz" başlıklı yazıda Abdülhak Hâmid'in şiirlerine atıfta bulunarak serbest vezni savunur. (Abdulhalim Memduh Bedriye, İstanbul: Mahmud Bey Matbaası, 1304/1888, s. 6). Gerçi bu fikirler Abdülhak Hâmid'in mektuplarında da vardır, ama o dönemde bu mektuplar yayımlanmış, dolayısıyla da kamusallaşmış değildir. Nureddin Ferruh'un metni ise (serbest vezni değil) veznin ve kafiyenin şiirde gerekli olmadığı fikrini savunan, yayımlanmış, dolayısıyla kamusallaşmış bir manifestodur. Ali İhsan Kolcu, "Daha on yedi yaşında iken yayımladığı Şafak Sadâları adlı kitabı kendi döneminde çok ses getirmemişse de edebiyat tarihi açısından özellikle de aruza, Farsça ve Arapça kelimelere, kurallara karşı başkaldırışın, serbest şiir hareketinin temel manifestolarından biri olmuştur" demekle bu durumu dillendirmiş olur (2017a: 34).

3 Ömür Aybar, 2013 yılında Şafak Sadaları'nın yayımlanma tarihi olan 1312 yılını (1331 okumuş ve) Hicri takvim üzerinden 1915 olarak hesaplamış ve yanlış tespit etmiş; üç y1l önce, yani 2010 yılında kendi makalesi ile aynı dergide (Turkish Studies) yayımlanmış olmasına rağmen Sevim Şermet'in kitabın mukaddimesinin yazılış tarihini (1311) referans alan Rumi takvime göre yaptığı doğru hesaplamayı (1895) görmemiş yahut görmezden gelmiştir. Nitekim Aybar, çalışmasında o tarihte Nureddin Ferruh hakkındaki yayımlanmış tek metin olan Şermet'in makalesini anmamıştır. (Ömür Aybar, "Nureddin Ferruh ve Şafak Sadaları Üzerine Bir İnceleme”, Turkish Studies, 8/4, Bahar 2013, s. 213-222.) Bu bir atıf değil, düzeltmedir. Ali İhsan Kolcu da Şermet'e atıf yapmaz fakat onun mukaddimeyi esas alan tarihlendirmesini kapakta yer alan yayımlanma tarihini (1312, Miladi 1896) tespit ederek düzeltir (2017a: 36).

4 Nureddin Ferruh'a dikkat çeken ve onu Türk edebiyatı tarihi içinde konumlandırdığını tespit edebildiğimiz ilk kaynak Hasan Kolcu'nun Türk Edebiyatında Hece-Aruz Tartışmaları adlı eseridir. Buna rağmen doğrudan Nureddin Ferruh'la ilgili tespit ettiğimiz ilk akademik yayını yapan Sevim Şermet, eserinin içinde Nureddin Ferruh'un şiirle ilgili görüşlerini alıntı ve aktarmalarla açıklayan Hasan Kolcu'ya herhangi bir atıfta bulunmamıştır. Bununla birlikte Şermet'in makalesi Nureddin Ferruh'un şiirle ilgili görüşlerini ciddiyetle ele alan, kapsamlı bir çalışmadır. Konuyla ilgili kitap oylumundaki ilk çalışma ise Ali İhsan Kolcu'nun Nureddin Ferruh Alkend: Hayatı-Sanatı-Eserleri adlı eseridir. Bununla birlikte, Ali İhsan Kolcu, kitabında Hasan Kolcu'ya da Sevim Şermet'e de atıfta bulunmaz.

5 https://de.wikipedia.org/wiki/Liste_der_t\%C3\%BCrkischen_Botschafter_in_Ungarn (Erişim 1 Şubat 2016)

6 Batı literatüründe "Avant la lettre".

7 Bize göre postmodern, modernite ile -onu üreten Batı geleneği hariç- geleneklerin teması/bir araya gelmesi sonucu ortaya çıkan bütün olası sonuçların ortak adıdır.

8 Hilmi Yavuz, "Parça'lı Modernleşme Olabilir mi?"

9 Felsefe literatüründe "Aşırı göstergeler"

10 III. Selim'in aynı konularda defaatle ferman yazmak durumunda kalması değişimin teşebbüsten fiiliyata geçişinin zorluğunu pek açık örnekler 
11 Bakış açısının altyapısı için bkz. Daryush Shayegan, Yaralı Bilinç, (İstanbul: Metis Yayınları, 2012).

$12 \mathrm{Bu}$ denemenin sonuçları itibariyle aynı anda hem "ne o ne de o" hem de "ya o ya da o" olması bu sebepledir. "Hem o hem de o" mümkün değildir.

13 Felsefe literatüründe "Simulasyon"

14 Felsefe literatüründe "Per se in se".

15 Bize göre "kültürel bünye" bir kültürün başka bir kültürün unsurlarını temellük edip edemeyeceğini, temellük edebilecekse hangi koşullarda, ne zaman ve nasıl temellük edeceğini belirleyen değerler ve öncelikler hiyerarşisidir. Edebiyatta bu hiyerarşinin en üstünde Roman Jakobson'ın "egemen öğe" dediği unsur bulunur. Vezin ve kafiyenin egemen öğeler olduğu Osmanlı şiirinin bünyesi vezinsiz ve kafiyesiz bir şiir anlayışını (doku uyuşmazlığı sebebiyle) kabul etmemiştir. Edebî bünye bir yeniliği en kolay yeni bir türle birlikte kabul eder. Bu sebeple kitaplara ad verilmesi, Osmanlı coğrafyasında roman türünün ortaya çıkması ile paralellik arz eder. Şinasi'nin hamlesine rağmen uzun süre şiir kitaplarına ad verilmesi kabul görmemiştir. Bu yüzden olsa gerek Müntahabât-ı Eş'âr'ın 4. ve 5. baskıları Şinasi Divanı adıyla basılır.

16 Ali İhsan Kolcu bu hususta şöyle der: “Şafak Sadâları'nda yazarın [...] Abdülkhâk Hâmid ve Recaizâde Ekrem'den mülhem görüşlerini bir kurgu dahilinde kotardığını görürüz”. Serbest Şiirin İlk Kuramcısı, (Erzurum: Salkımsöğüt Yayınevi, 2017), s./ p. 37.

17 Gülşen 22 (24 Temmuz 1302): 85. M. Fatih And1, Servet-i Fünûn'a Kadar Yeni Türk Şiirinde Şekil Değişmeleri, (İstanbul: Kitabevi, 1997), s./ p. 359.

18 Ayrıca, Osmanlı şiirinde 19. yüzyıl sonlarına kadar kafiye kulağa değil, göze yönelik kabul edildiğine göre bütün Divan şiiri bir bakıma "görsel"dir.

19 Osmanlı Ahrar Fırkası’nın kurucularındandır (Kaluç 195).

\section{Kaynaklar}

Abdulhalim, M. (1304/1888). Bedriye. İstanbul. Mahmud Bey Matbaas1.

Akın, H. (2001). Servet-i Fünun nazmında vezin, şekil ve kafiye. (Yayımlanmamış Yüksek Lisans Tezi) Samsun Ondokuz Mayıs Üniversitesi.

And1, M.F. (1997). Servet-i Fünûn'a kadar yeni Türk şiirinde şekil değişmeleri. İstanbul: Kitabevi.

Bruijn, P. (1997). The world of Eşber. Leiden. Research School CNWS.

Cohen, J. (1966). Structure du langage poétique. Paris. Flammarion.

Ferruh, N.(1312/1896). Şafak sadâları. İstanbul: Şirket-i Mürettebiye.

Ferruh, N. (1312/1896). Sanat. Malumat. 33-34, s. 710-12.

Ferruh, N. (1312/1896). Sanat. Malumat. 40, s. 869-71.

Ferruh, N. (1312/1896). Sanat. Servet-i Fünun, 11. İstanbul s. 262.

Genette, G. (1969). Figures II. Paris: Éditions de Seuil.

Kaluç, Ş (2009). Osmanlı Ahrar fırkasının kuruluşu, faaliyetleri ve sonu. Liberal Düşünce 53 s. $177-213$.

Karatani, K. (2011). Çocukluğun keşfi, derinliğin keşfi. İstanbul: Metis Yayınları, s. 135-158. Kebeli, S. (2007). Sömürgeciliğe karşı: Abdülhak Hâmid tiyatrosu. (Yayımlanmamış Yüksek Lisans Tezi), Ankara: Bilkent Üniversitesi.

Kolcu, A.İ. (2017). Serbest şiirin ilk kuramcısı: Nureddin Ferruh Alkend: Hayatı-sanatıeserleri. Erzurum. Salkımsöğüt. 
Kolcu, H. (1993). Türk edebiyatında hece-aruz tartışmaları. Ankara: Kültür Bakanlığı. Menemencioğlu, N. (1978). Modern Turkish poetry: 1850-1975. Nermin Menemencioğlu (ed.), The Penguin Book of Turkish verse, New York: Penguin Books, s. 47-57.

Samsakç1, M. (2012). Şiir nesir olmayan söz müdür? Turkish Studies, 7/4, s. 2709-2724.

Shayegan, D. (2012). Yaralı bilinç. Çev. Haldun Bayrı. İstanbul: Metis.

Şermet, S. (2010). Serbest şiirin tarihine girişte unutulan bir isim: Nurettin Ferruh ve şiir sanat1. Turkish Studies, 5/2), s. 1333-1352.

Törenek, M. (2010). Şiirimizde yenileşme süreci ve serbest şiir. Turkish Studies, 5/2, s. 13-49. Uçman, A. (2012). Tevfik Fikret-Rıza Tevfik. İstanbul Üniversitesi Edebiyat Fakültesi Türk Dili ve Edebiyatı Dergisi, 34, s. 211-235.

Uçman, A. (2014). Tanzimat’tan sonra Türk şiirinde değişme ve yenileşmeler üzerine bir deneme. Türklük Bilimi Araştırmaları, 19, s. 477-488.

Elektronik kaynak:

Yavuz, H. Parça'lı modernleşme olabilir mi? (26.01.2018). http://baysungur.blogspot.com. tr/2009/07/parcal-modernlesme-olabilir-mi.html 